\title{
Konseling Individual dalam Mengatasi Prilaku Agresif Siswa
}

\author{
Widia Fauza ${ }^{1}$, Wan Chalidaziah ${ }^{2}$ \\ ${ }^{12}$ Bimbingan dan Konseling Islam, Institut Agama Islam Negeri Langsa \\ 1idiafauza5@gmail.com
}

$\begin{array}{ccc}\text { First received: } & \text { Revised: } & \text { Final Accepted: } \\ 25 \text { April } 2021 & 25 \text { Mei } 2021 & 04 \text { Juni } 2021\end{array}$

\begin{abstract}
This study aims to determine the implementation of individual counseling to overcome the aggressive behavior of SMA 1 Idi Rayeuk students and to determine the supporting and inhibiting factors for the implementation of individual counseling in overcoming aggressive behavior of SMA 1 Idi Rayeuk students. This research is a case study research (case study), the approach used in this research is qualitative. Sources of research data, namely counseling guidance teachers at SMA 1 Negeri Idi Rayeuk 2 people, and 7 students, data collection techniques by means of observation interviews and documentation. The results of this study indicate that the implementation of individual counseling on aggressive students using individual counseling, individual counseling overcoming serious student problems. Meanwhile, for mild student problems, it is enough only to be reprimanded and advised by the homeroom teacher and counseling teacher. The stages of individual counseling for students who engage in aggressive behavior are carried out in three stages, the opening stage, the core activity stage and the closing stage, the results obtained for the implementation of individual counseling on students at SMA Negeri 1 Idi Rayeuk are fruitful, students begin to be able to face all problems patiently and a cool head. Students have the ability to make choices or actions for their survival. Students have also started to gradually change their behavior, students have also started to open themselves up to communicate with their closest people such as their parents, siblings and friends.
\end{abstract}

Keywords: Individual Counseling, Aggressive Behavior, Student

\begin{abstract}
Abstrak
Penelitian ini bertujuan untuk mengetahui penerapan pelaksanaan konseling individual untuk mengatasi perilaku agresif siswa SMA 1 Idi Rayeuk serta untuk mengetahui faktor pendukung dan penghambat pelaksanaan konseling individual mengatasi prilaku agresif siswa SMA 1 Idi Rayeuk. Penelitian ini merupakan penelitian studi kasus (study case), pendekatan yang digunakan dalam penelitian ini adalah kualitatif. Sumber data penelitian yaitu guru bimbingan konseling di SMA 1 Negeri Idi Rayeuk 2 orang, dan siswanya sebanyak 7 orang, teknik pengumpulan data dengan cara observasi wawancara dan dokumentasi. Hasil penelitian ini menunjukan bahwa pelaksanaan konseling individual pada siswa yang agresif menggunakan konseling individual, bimbingan konseling individual mengatasi permasalahan-permasalahan siswa yang berat. Sementara untuk masalah siswa yang ringan cukup hanya dilakukan teguran dan dinasehati oleh wali kelas dan guru BK. Tahapan konseling individual pada siswa yang melakukan perilaku agresif dilakukan tiga tahapan, tahap pembukaan, tahap inti kegiatan dan tahap penutupan, hasil yang di dapat terhadap pelaksanaan konseling individual pada siswa di SMA Negeri 1
\end{abstract}


Idi Rayeuk membuahkan hasil, siswa mulai bisa menghadapi segala persoalan dengan sabar dan kepala dingin. Siswa memiliki kesanggupan untuk mengambil pilihan atau tindakan untuk kelangsungan hidupnya. Siswa juga sudah mulai berangsur-angsur bisa mengubah perilakunya, siswa juga sudah mulai membuka diri berkomunikasi dengan orang-orang terdekat seperti orang tua, saudara-saudaranya dan temantemannya.

Kata Kunci : Konseling Individual, Prilaku Agresif, Siswa

\section{PENDAHULUAN}

Berbagai masalah di era modern saat ini menuntut pihak sekolah untuk meningkatkan profesional konselor, sehingga konselor mampu memecahkan setiap masalah yang dialami siswa, baik pribadi maupun sosial. Kompleksnya masalah di era globalisasi memang sulit untuk dikendalikan. Globalisasi maju dengan kecepatan dasyat dan selalu menimbulkan masalah psikologis, moral, mental, pemikiran, maka disinilah salah satu fungsi bimbingan dan konseling dalam membantu siswa agar mampu menjaga diri dari berbagai godaan dan penyimpangan (Asmari, J, M. 2010).

Perkembangan usia remaja merupakan puncak emosionalitas, yaitu perkembangan emosi yang tinggi. Pada usia remaja, perkembangan emosinya menunjukkan sifat yang sensitif dan reaktif yang sangat kuat terhadap berbagai peristiwa atau situasi sosial, emosinya bersifat negatif dan temperamental (mudah tersinggung/marah, atau mudah sedih/murung), sedangkan remaja akhir sudah mampu mengendalikan emosinya.

Menghadapi ketidaknyamanan emosional, tidak sedikit remaja yang mereaksikanya secara defensif, sebagai upaya untuk melindungi dirinya, reaksinya itu tampil dalam tingkah laku seperti: 1) agresif, seperti melawan, keras kepala, bertengkar, berkelahi, dan mengganggu orang lain, dan 2) melarikan diri dari kenyataan, melamun, pendiam, senang menyendiri, dan minumminuman keras (Williamson. E. G. 2011).

Fakta yang terjadi dilapangan, masa remaja mempunyai tempat yang tidak jelas dalam rangkaian proses perkembangan seseorang, masa ini merupakan masa peralihan remaja ke dewasa menitik beratkan pada tugas perkembangan pada masa remaja ${ }^{6}$. Dalam praktiknya, interaksi edukatif tidaklah bisa berjalan tanpa adanya pendidik, dalam hal ini guru sebagai figur manusia yang menjadi sumber dan menempati posisi penting dalam pendidikan. Secara sederhana, guru 
adalah orang yang memberikan ilmu pengetahuan kepada siswa. Tanpa guru pendidikan tidak ada artinya dan tidak bisa menghapus kebodohan dalam diri manusia.

Fenomena permasalahan saat ini menjelang, remaja ke dewasa mengalami banyak pengaruh dari luar yang menyebabkan remaja terbawa pengaruh oleh lingkungan tersebut. Sehingga remaja yang tidak bisa menyesuaikan atau beradaptasi dengan lingkungan yang selalu berubah ubah mengakibatkan perilaku yang maladatif, seperti contohnya perilaku agresif yang dapat merugikan orang lain dan juga diri sendiri (Puspitasari, D, N. 2019). Sekolah Menengah atas Idi Rayeuk merupakan salah satu sekolah yang memiliki (2) dua orang guru Konseling, Guru konseling di sekolah ini ada yang latar belakang pendidikannya BK dan ada yang bukan.

Penyimpangan-penyimpangan, pelanggaran terhadap norma, serta aturan yang ada sering dilanggar oleh siswa di sekolah Karena siswa yang duduk di bangku sekolah berada pada masa remaja yang merupakan masa perkembangan. Adanya berbagai masalah yang dihadapi siswa dapat di seselaikan dengan bantuan guru BK. Menurut Latif, A (2019) Guru BK memberikan layanan konseling individual disekolah memungkinkan peserta didik mendapatkan pelayanan langsung tatap muka yang diselenggarakan oleh seorang konselor terhadap seorang klien dalam rangka pengentasan masalah-masalah pribadi klien.

Dalam suasana tatap muka dilaksanakan interaksi langsung antara klien dan konselor membahas berbagai hal tentang masalah yang dialami klien maupun mengatasi masalah sendiri, dan dapat menyesuaikan diri secara positif sehingga siswa mampu terbuka terhadap masalah yang dimilikinya melalui proses layananan konseling. Hal ini aka nada bila Guru BK memiliki kemampuan untuk menjadi seseorang yang signifikan bagi siswa sehingga siswa mampu terbuka atas permasalahannya. (Nurihsan, A, J. 2017; Chalidaziah, W. 2019). Layanan konseling individual mengaktifkan dinamika untuk membahas berbagai hal yang berguna bagi pengembangan pribadi dan pemecahan masalah individu yang menjadi peserta layanan (Latif, A. 2019).

Berdasarkan survey awal yang dilakukan disekolah SMA Negeri 1 Idi Rayeuk dengan melakukan wawancara kepada guru bimbingan konseling, data yang didapatkan bahwa ada beberapa siswa sehari-harinya berperilaku suka memaki 
temanya dengan kasar, langsung dihadapan temannya, menghina, selalu mengjahili temannya dikelas, dan memukul temannya sendiri. Melihat fenomena perilaku siswa tersebut, maka peneliti tertarik untuk melakukan penelitian yang berjudul "Penerapan Konseling Individual Dalam Mengatasi Prilaku Agresif".

\section{Metodologi}

Jenis penelitian yang akan digunakan dalam penelitian ini adalah jenis penelitian studi kasus (study case), menurut Andi Prastowo. "Studi kasus adalah suatu inquiri empiris yang menyelidiki fenomena dalam konteks kehidupan nyata"(Prastowo, A. 2015). Menurut Sugiono (2012) Studi kasus digunakan sebagai suatu penjelasan komprenshif yang berkaitan dengan berbagai aspek seseorang, suatu kelompok, suatu organisasi, suatu program, atau situasi kemasyarakatan yang diteliti, diupayakan dan telaah sedalam mungkin.

Tujuan penelitian studi kasus adalah untuk mempelajari secara mendalam dan sistematis dalam kurun waktu cukup lama tentang sesuatu kasus sehingga dapat dicari alternatif pemecahannya. Mendalam, artinya mengungkap dan menggali data secara mendalam dan menganalisis secara intensif factor-faktor yang dapat menyebabkan terjadinya kasus tersebut. Tekanan utama dalam studi kasus adalah mengapa individu melakukan itu? Apa yang dia lakukan setiap harinya? Bagaimana hubungan sosial dia dengan teman-temannya? Faktor-faktor apa yang mempengaruhi tindakannya tersebut?

Berdasar pada pandangan di atas, maka penelitian kualitatif dalam tulisan ini dimaksudkan untuk menggali suatu fakta, lalu memberikan penjelasan terkait berbagai realita yang ditemukan. Oleh karena itu, peneliti langsung mengamati peristiwa-pristiwa di lapangan yang berhubungan langsung dengan penerapan Konseling Individual dalam mengatasi Prilaku Agresif Siswa di SMA 1 IDI Rayeuk.

Pendekatan yang dilakukan dalam penelitian ini adalah pendekatan kualitatif. Artinya, data yang di kumpulkan bukan berupa angka-angka, melainkan data tersebut berasal dari naskah wawancara, catatan lapangan, dokumen pribadi, dan dokumen resmi lainya, baik itu dokumen dalam instansi penelitian maupun lembaga, sehingga yang menjadi tujuan dari penelitian kualitatif ini adalah ingin menggambarkan realita yang di balik fenomena secara mendalam, rinci dan tuntas. Prosedur penelitian kualitatif untuk mengahasilkan data deskriptif berupa 
kata-kata tertulis atau lisan dari orang orang dan perilaku yang dapat diamati.

Teknik pengumpulan data merupakan langkah strategis dalam penelitian karena tujuan utama dari penelitian adalah mendapatkan data. Dalam penelitian ini teknik pengumpulan data yang digunakan antara lain:

a. Observasi

Observasi pada penelitian tertuju pada aktivitas layanan konseling individual yang di laksanakan oleh guru BK dan perubahan tingkah laku siswa yang terjadi.

b. Wawancara

Wawancara yang dilakukan pada penelitian tertuju pada subjek penelitian yaitu Guru BK dan Siswa yang di berikan Layanan konseling Individual. Wawancara yang dilakukan bertujuan untuk memperdalam hasil penelitian.

c. Studi Dokumentasi

Adapun yang dimaksud studi dokumentasi adalah memperoleh data mengenai model konseling yang di gunakan oleh seorang konselor dalam menangani prilaku agresif di SMA Negeri 1 Idi Rayeuk. Serta melihat penilaian yang di laksanakan serta hasil perubahan yang diperoleh Guru BK.

\section{HASIL TEMUAN}

Berdasarkan penelitian yang penulis lakukan layanan konseling individu untuk mengatasi perilaku agresif siswa maka hasil penelitian ini dapat ditarik kesimpulan bahwa:

1) Pelaksanaan konseling individual untuk mengatasi perilaku agresif siswa yaitu, untuk permasalahan yang ringan hanya dilakukan teguran dan dinasehati oleh wali kelas dan Guru BK, terkadang jika melakukan hal yang ringan dan berulang kali maka guru BK menekankan untuk memberikan hukuman seperti membersikan lingkungan sekolah serta memberikan sanksi administertif terdiri dari peringatan, teguran, nasehat. Tahapan yang dilakukan dalam konseling induvidual pada siswa yaitu, (1) Tahap pembukaan (awal), tahap ini merupakan tahap pertama dalam kegiatan konseling individual. Pada tahap ini seorang guru BK membangun hubungan baik dengan siswa. Dan mengidentifikasi masalah serta langkah diagnosis. (2) Tahap inti kegiatan (pertengahan), tahap ini merupakan tahap pelaksanaan kegiatan konseling, Pada tahap inti kegiatan ini ialah tahap disaat guru BK mendifinisikan masalah siswa, mencari solusi alternatif bagi siswa, memutuskan 
rencana solusi menggunakan metode layanan konseling individual (3)Tahap penutupan (pengakhiran) Pada tahap ini konseli menyatakan pemantapannya atas keputusan yang diambil (4) Tindak lanjut (Follow up) Pada langkah follow up ini, konselor mengamati sampai sejauh mana yang dilakukan dalam terapi. Sehingga dengan langkah-langkah ini konselor dapat mengontrol efektifitas perjalanan siswa.

2) Faktor pendukung dan penghambat pada pelaksanaan konseling individual di SMA 1 Idi Rayeuk, faktor pendukung yaitu tentang kemampuan profesional konseling ke dalam layanan bimbingan dan konseling di sekolah lebih banyak ditunjang oleh hal-hal yang berasal dari diri konseling itu sendiri. semangat dan ketulusan atau keikhlasan guru BK nya dalam melaksanakan layanan terhadap siswanya yang bermasalah, sedangkan faktor penghambat nya adalah (1) Masih banyaknya siswa yang belum memahami perlunya layanan bimbingan dan konseling baik itu individual dalam mengatasi berbagai masalah di lingkungan sekolahnya, tidak hanya masalah agresif siswa akan tetapi masih banyak hal yang perlu di bimbing terhadap siswa (2) Siswa masih banyak yang takut datang meminta layanan konseling, mereka banyak merahasiakan masalah baik itu rahasia permasalahan di sekolah maupun masalah siswa di rumah yang dibawa ke lingkungan sekolahnya. (3) Orang tua siswa dan pihak-pihak lainnya belum memberikan dukungan yang penuh terhadap terselenggaranya berbagai tugas layanan bimbingan dan konseling di sekolah.

\section{PEMBAHASAN}

Perilaku terjadi apabila ada sesuatu yang diperlukan untuk menimbulkan reaksi, yang disebut rangsangan. Berarti rangsangan tertentu akan menghasilkan perilaku tertentu. Menurut Asmari, M, J (2010) “Perilaku individu tidak timbul dengan sendirinya, tetapi sebagai akibat adanya rangsangan (stimulus) baik dari dalam dirinya sendiri (internal) maupun dari luar individu (eksternal)" (Riyanthi, B. 2016). Pada hakekatnya perilaku individu mencakup perilaku yang tampak (overt behaviour) dan perilaku yang tidak tampak (inert behavior atau covert behavior). Rangsangan ini di perkuat oleh Pendapat Carter., E.,C., McCullough yang di kutip oleh Juntika dalam jurnal ilmiahnya bahwa "Perilaku yang tampak adalah perilaku yang dapat diketahui oleh orang 
lain tanpa menggunakan alat ke tangan temannya, atau mengayunbantu"(Carter, E, C \& McCullough. 2012), sedangkan perilaku yang tidak tampak adalah perilaku yang hanya dapat dimengerti dengan menggunakan alat atau metode tertentu, misalnya berpikir, sedih, berkhayal, bermimpi, takut.

Perilaku yang tampak dalam pribadi individu dalam menghadapi stimulus mengakibatkan dua perilaku yaitu pertama, perilaku asertif dan kedua, perilaku agresif. Perilaku agresif Asertivitas (asertif) adalah suatu kemampuan untukmengkomunikasikan apa yang diinginkan, dirasakan, dan dipikirkan kepada orang lain namun dengan tetap menjaga dan menghargai hakhak serta perasaan pihak lain (Sari, D, N, P. 2015).

Bersikap asertif, seseorang dituntut untuk jujur terhadap dirinya dan jujur pula dalam mengekspresikan perasaan, pendapat dan kebutuhan secara proporsional, tanpa ada maksud untuk memanipulasi, memanfaatkan ataupun merugikan pihak lainnya. Perilaku agresif adalah individu cenderung (ingin) menyerang kepada sesuatu yang dipandang sebagai hal yang mengecewakan, menghalangi atau menghambat. Perilaku ini dapat membahayakan anak atau orang lain. misalnya, menusukan pensil yang runcing ngayunkan tasnya sehingga mengenai orang yang berada di sekitarnya (Sari, D, N, P. 2015).

Bentuk perilaku agresif ini sesuai dengan pernyataan yang di kemukakan oleh ibu Devi Surasti dan ibu Elvinda. Bentuk perilaku memukul, mendorong, merupakan bentuk perilaku agresif fisik ditandai dengan ciri-ciri mendominasi orang lain, menggigit, menendang, memberontak, mengganggu, merusak, mendorong, menyerang, marah yang sadis, berkelahi, memukul dan perilaku destruktif yang mengganggu hak orang lain.

Perilaku agresif fisik yang dilakukan oleh siswa termasuk perilaku agresif tersinggung yaitu tipe agresif yang terjadi akibat adanya rasa tersinggung dan mendorong seseorang untuk bertindak menyerang dan melukai seseorang yang membuat dirinya merasa tersinggung maupun menyerang objek mati seperti contohnya melempar penghapus ke papan tulis (Salmiati, 2015). Perilaku tersebut seperti yang di ungkapkan oleh E.G Williamson dan J.D Darley, Perilaku agresif, merupakan suatu bentak menyakiti orang lain yang dapat meyebabkan kerusakan fisik maupun mental. Perilaku agresif dapat dilakukan karena adanya tujuan tertentu ataupun 
tidak adanya tujuan tertentu hanya untuk pelampiasan semata (Carter, E, C, McCullough, 2015).

Berdasarkan analisis data dari hasil pengamatan dan wawancara menunjukkan bahwa bimbingan konseling Individual dapat mengatasi perilaku agresif pada siswa setelah mendapatkan layanan konseling individual. Hasil penelitian ini juga menunjukkan adanya bahwa rata-rata perilaku agresif setelah adanya layanan konseling individu lebih rendah dibanding dengan sebelum mendapatkan layanan konseling individual. Hal ini menunjukkan layanan konseling individual yang dilakukan setelah permasalahan siswa diketahui dilakukan dengan efektif, dimana konselor bekerja sama dengan wali kelas, dan orang tua, dan juga kepala sekolah. Layanan konseling individual menjadi efektif tidak hanya karena kerjasama antara wali kelas, waka kesiswaan, dan kepala sekolah saja, melainkan dengan adanya home visit dan juga adanya riferal antar konselor.

Layanan konseling individual yang sudah dilakukan kepada siswa yang berperilaku agresif merupakan upaya bantuan yang diberikan kepada siswa bertujuan untuk mengembangkan pribadi siswa guna mencapai suatu pemecahan masalah pribadi yang dialami oleh siswa (Asrori, M. 2008). Bantuan yang diberikan kepada siswa melalui layanan konseling individual memberikan dampak positif terhadap perkembangan terutama dalam mengurangi perilaku agresif siswa secara fisik agresif adalah perilaku yang disengaja untuk melukai orang lain baik fisik maupun verbal terhadap individu atau objek-objek lain(memukul, mendorong, berkelahi, merusak, mencubit, menendang, dan mengganggu) dan secara verbal (menghina, mencaci-maki, berkata kotor, membentak, menggunjing, dan berkata kasar kepada siswa lain).

Menurut teori perilaku agresif merupakan tingkah laku pelampiasan dari perasaan frustasi atau mengatasi perlawanan dengan kuat atau menghukum orang lain, yang ditujukan untuk melukai pihak lain secara fisik maupun psikologis pada orang lain yang dapat dilakukan secara fisik maupun verbal.

Tujuan khusus diadakannya bimbingan dan konseling individual di SMA negeri 1 Idi rayeuk adalah seperti yang dijelaskan oleh Hamdan (Budhi, I. 2018) menjelaskan sebagai berikut:

1. Untuk menghasilkan suatu perubahan, perbaikan, remaja menjadi tenang, bersikap lapang dada dan mendapatkan pencerahan 
2. Untuk menghasilkan suatu perubahan, perbaikan dan kesopanan tingkah laku remaja yang dapat memberikan manfaat baik dari diri sendiri, lingkungan keluarga, dan lingkungan sosial dimana remaja bertempat tinggal.

3. Untuk menghasilkan kecerdasan spiritual pada diri remaja sehingga muncul dan berkembang, rasa keinginan untuk berbuat taat mematuhi segala perintah

Untuk menghasilkan potensi ilmiah remaja, sehingga dengan potensi itu remaja dapat melakukan tugasnya dengan baik dan benar, remaja dapat menanggulangi berbagai persoalan hidup, dan dapat memberikan kemanfaatan dan keselamatan bagi lingkungannya pada berbagai aspek. Melihat adanya tujuan tersebut, hal inilah yang ingin dicapai oleh pelaksanaan konseling individual yang dilaksanakan di SMA Negeri 1 Idi Rayeuk.

\section{PENUTUP}

\section{Kesimpulan}

Berdasarkan hasil pemaparan yang telah di sampaikan maka dapat disimpulkan bahwa (a) pelayanan konseling individual yang dilaksanakan di Sekolah dalam menangani permasalahan berkaitan dengan prilaku agresif dap di lakukan dengan Langkah-langkah konseling individual dan serta ditambahkan dengan reinforcement baik positif maupun negative kepada siswa guna untuk mempertahankan prilaku baik serta meminimalisir prilaku agresif yang dimiliki. (b) Adapun hambatan yang dimiliki saat proses prelaskanaan adalah profesionalisme guru BK itu sendiri serta dukungan dari stageholder disekolah.

\section{Saran}

Berdasarkan kesimpulan yang ada penulis mengajukan saran kepada pelaksanaan setiap kegiatan BK disekolah sendaknya memiliki hasil kerja yang nyata serta memiliki dokumentasi yang yang lengkap sehingga setiap masyaakat sekolah dapat merasakan makna keberadaan BK disekolah. Serta pada peneliti selanjutnya untuk meneliti aspek lainnya pada layanan konseling individual agar praktiknya lebih mendalam.

\section{DAFTAR PUSTAKA}

Asmari, M, J. (2010). Bimbingan dan Koseling di Sekolah, Jakarta: Diva Prees.

Chalidaziah, W. (2019). Sasaran Dan Topik Pembahasan Self Disclosure Mahasiswa. ENLIGHTEN: Jurnal Bimbingan Konseling Islam, 2(2), 112121. https://doi.org/10.32505/enlighten.v 2i2.1363

Irvan, B. (2018). Perilaku Agresi Pada Siswa SMK di Yogyakarta, Jurnal Fokus Konseling, Vol 4, No. 1 
Latif, A. (2019). Upaya Menurunkan Perilaku Agresif melalui Pemberian Layanan Konseling Individual pada Siswa. Jurnal Penelitian Pendidikan, Vol, 3 -ISSN 1412-565.

McCullough, E, C., \& Carter. (2012). Self Control Social Psychology and Personality Science, Journal, Vol 2 No 6, Desember.

Nurihsan, A,N. (2017). Strategi Layanan Bimbingan dan Konseling, Bandung: Grafika aditama

Prastowo, A. (2015). Memahami MetodeMetode Penelitian. Yogyakarta: Arruzz Media.

Puspitasari, D. N. (2019). Pelatihan Keterampilan Sosial untuk Menurunkan Perilaku Agresif Anak. Jurnal Psikologi Tabularasa, vol 9 -eISSN 2541.

Salmiati. (2015) Perilaku Agresif dan Penanganannya, (Jurnal Psikologi Pendidikan \& Konseling Vol 1 No 1, ISSN: 2443-2202 Juni 2015

Williamson. E. G. (2011). “Temperature and aggression: Paradox, controversy, and a (fairly) clear picture". (Terj) Badrun Susantyo, Jurnal Vol. 16 No. 03 hal 12-21. 